\title{
Anti-Alzheimer's and Anti-inflammatory Activities of Compounds Isolated from Solanum Mauritianum
}

\section{()(1) $\odot \Theta$}

\author{
Authors \\ Luis Apaza Ticona ${ }^{1,2}$, Borja Durán García ${ }^{1}$, Marcos Humanes Bastante ${ }^{1}$, Andreea Madalina Serban ${ }^{3}$, \\ Ángel Rumbero Sánchez ${ }^{1}$
}

\section{Affiliations}

1 Department of Organic Chemistry, Faculty of Sciences, University Autónoma of Madrid, Cantoblanco, Madrid, Spain

2 Department of Pharmacology, Pharmacognosy and Botany, Faculty of Pharmacy, University Complutense of Madrid, Ciudad Universitaria s/n, Madrid, Spain

3 Maria Sklodowska Curie University Hospital for Children, Bucharest, Romania

Key words

Solanaceae, Solanum mauritianum, anti-inflammatory, anti-cholinesterase, anti-Alzheimer's

received $\quad 04.08 .2021$

revised 21.09 .2021

accepted 09.11 .2021

\section{Bibliography}

Planta Med Int Open 2022; 9: e1-e11

DOI 10.1055/a-1696-6741

ISSN 2509-9264

(C) 2022. The Author(s).

This is an open access article published by Thieme under the terms of the Creative Commons Attribution-NonDerivative-NonCommercial-License, permitting copying and reproduction so long as the original work is given appropriate credit. Contents may not be used for commecial purposes, or adapted, remixed, transformed or built upon. (https://creativecommons. org/licenses/by-nc-nd/4.0/)

Georg Thieme Verlag KG, Rüdigerstraße 14,

70469 Stuttgart, Germany

\section{Correspondence}

Prof. Dr. Luis Apaza T.

Department of Organic Chemistry

Faculty of Sciences

University Autónoma of Madrid

Cantoblanco

Street Francisco Tomás y Valiente, 7

28049 Madrid

Spain

Tel.: + 34/91/497 7622, Fax: + 34/91/497 4715

Inapaza@ucm.es or luis.apaza@uam.es

\begin{abstract}
Supplementary material is available under https://doi.org/10.1055/a-1696-6741.
\end{abstract}

\begin{abstract}
Solanum mauritianum, commonly known as "Tabaquillo", was one of the most used plants by tribes from South America as a remedy for headaches. Based on this ethnopharmacological use, a bioguided isolation of compounds with anti-inflammatory and anti-Alzheimer's activities from $S$. mauritianum was carried out by measuring the inhibition of NF- $\kappa$ B in C8D1A, Neuro-2a, and EOC 13.31 cells, and by measuring the inhibition of acetylcholinesterase and $\beta$-amyloid. This allowed the isolation and characterisation by nuclear magnetic resonance and mass spectrometry of four compounds (1-4). Compounds 1-4 showed NF- $K B$ inhibitory activity with $\mathrm{IC}_{50}$ values of 9.13-9.96, 17.17-17.77, 2.41-2.79, and 1.59-1.93 $\mu \mathrm{M}$, respectively, while celastrol (the positive control) had an $\mathrm{IC}_{50}$ value of $7.41 \mu \mathrm{M}$. Likewise, compounds 1-4 showed anti-Alzheimer's activity, inhibiting the acetylcholinesterase by $40.33,20.57,61.26$, and $83.32 \%$, respectively, while galantamine (positive control) showed an inhibition of $90.38 \%$. In addition, concerning the inhibition of $\beta$-amyloid aggregation, compounds $\mathbf{1 - 4}$ showed an inhibition of $47,23,65$, and $93 \%$, respectively, while curcumin (positive control) had an inhibition of $71.19 \%$.
\end{abstract}




\section{Introduction}

Alzheimer's disease (AD) is a worldwide health problem that was noted as the sixth top cause of death in the United States in 2015 [1]. In 2015, an estimated 46.8 million people worldwide suffered from $A D$, and this number is expected to rise to 131.5 million in 2050 with a subsequent increase in social and financial burdens [2].

$A D$ is a progressive and neurodegenerative disorder among the elderly, characterised by progressive loss of memory and cognition [3]. In the early stages of $A D$, people have trouble remembering recent events, also called short-term memory loss. In the following stages, other symptoms arise, such as problems with communication through language, disorientation, loss of motivation, neglect in self-care, sleep disorders, and behavioural issues increasing in intensity [4]. In the late stage of AD, patients may not recognise family, and gradually the brain functions are lost due to damage at the level of the central nervous system, leading to death [5].

This is caused by brain damaged neurons and neurites, and highly insoluble $\beta$-amyloid $(\mathrm{A} \beta)$ peptide deposits and intracellular neurofibrillary tangles (NFTs), providing stimuli for inflammation [6]. This inflammation in the nerve tissue is characterised by the activation of astrocytes and microglia, and by the activation of cytokines and chemokines. Microglia are the primary carriers of the inflammatory reaction, forming approximately $10 \%$ of all brain cells. The activation of microglia is based on extracellular deposition of $A \beta$ plaques, neuronal damage induced by the toxicity of the T-protein, or after ischemic or traumatic brain injury during AD progression [7].

Moreover, the macrophage-like resident immune cells in the brain also play an inflammation role in the development of AD. Thus, the microglia are activated by oligomeric and fibrillar particles of $A \beta$ and by substances of degenerated neurons that increase their migration and phagocytosis. These main neurotoxic molecules produced by activated microglia are reactive oxygen species, glutamate, and proinflammatory cytokines (TNF- $\alpha$ and IL-1 $\beta$ ) [8].

The current diagnosis of AD is made by mental and cognitive examinations. From a histopathological point of view, this means the presence of senile $A \beta$ plaques and NFTs in brain tissue, the two main hallmarks of AD [9]. Although several compounds undergoing research appear to be protective and have therapeutic effects in the $A D$ model, none of these drugs was able to stop or reverse the course in patients with $A D$ [10]. Acetylcholinesterase (AChE) inhibitors are the main existing therapeutic agents for AD treatment, which temporarily decrease dementia by raising the neurotransmitter level [11]. Despite extensive studies on new drugs for $A D$ treatment, none has been successful from this point of view, leading to the need for further research [12].

Natural compounds (natural extracts and bioactive compounds) are an emerging approach for AD therapy [13]. The first natural product studied in a clinical trial was nicotine in 1992. However, no new clinical trials were performed in the last two decades for this compound [14]. During the ' 90 s, several other compounds were studied in clinical trials for AD therapy, such as vitamins [15]. These compounds are still being tested in human trials today. Other natural compounds have been moved to the clinical trials phase, such as curcumin (Curcuma longa), huperzine A (Huperzia serrata), and bryostatin (Bugula neritina), whose effects started to be evaluated in humans in 2017 [16].
In this context, Solanum (Solanaceae) is a genus of approximately 1230 species. Its extracts are obtained from different parts, such as leaves, stems, bark, and roots, and have been used in the ethnomedicine of different cultures [17]. Different compounds with anti-Alzheimer activity have been isolated from these species, e. g., Solanum asperum [18], Solanum nigrum, Solanum macrocarpon [19], and Solanum betaceum [20].

In this report, we analyse a different and less known species of this genus, Solanum mauritianum Scop., commonly known as "Tabaquillo". This species is native from north-eastern Argentina, Southern Brazil, Paraguay, and Uruguay, and the infusions from its leaves have been used in traditional medicine against fever and headaches [21,22]. To date, only four compounds present in this species have been characterised, all of them of an alkaloid structure (solasodine, solasonine, solamargine, and caulophyllum-A) [23]. Recently, Pelo et al. [21] mentioned the presence of phenols, flavonoids, quinones, saponins, and cardiotonics through qualitative colouration reactions. Finally, with respect to the pharmacological activities of the species $S$. mauritianum, only antioxidant and antitumoral effects have been reported $[24,25]$.

This study reports the isolation of four compounds (1-4) with an inhibitory effect on NF- $K B$ as well as their inhibitory effect on cholinesterase and $\mathrm{A} \beta$ aggregation.

\section{Results and Discussion}

Using hexane (HEX), dichloromethane (DCM), $\mathrm{MeOH}$, and distilled water $\left(\mathrm{DH}_{2} \mathrm{O}\right)$, four extracts of increasing polarity were obtained from dry powdered leaves of S. mauritianum. To evaluate their complexity and to perform an initial identification of the metabolite groups present in each of the extracts, ${ }^{1} \mathrm{H}$ NMR spectra of each of them was recorded (Figs. 1S-5S, Supporting Information). The $n$ HEX and DCM extracts showed a group of intense signals in the aliphatic zone $\left(\delta_{H} 2.5-0.5 \mathrm{ppm}\right)$, corresponding to hydrogens located in aliphatic chains.

Moreover, the ${ }^{1} \mathrm{H}$ NMR spectra of $n-\mathrm{HEX}, \mathrm{DCM}$, and $\mathrm{MeOH}$ showed signals between $\delta_{H} 5.5-5.0 \mathrm{ppm}$, which correspond to the presence of olefinic-type protons, and around $\delta_{\mathrm{H}} 4.5-3.7 \mathrm{ppm}$, corresponding to hydrogens close to heteroatoms such as ethers, amines, or alcohols. Finally, less intense signals were observed around $\delta_{\mathrm{H}} 8.0-6.0 \mathrm{ppm}$, corresponding to the presence of aromatic compounds. In addition, the $\mathrm{MeOH}$ extract presented a group of signals at $\delta_{\mathrm{H}} 1.2-0.7 \mathrm{ppm}$, which corresponds to shorter alkyl chains. Finally, the aqueous extract presented a group of signals around $\delta_{\mathrm{H}} 4.5-3.5 \mathrm{ppm}$, which corresponds to glycosylated compounds.

According to the observed signals, the $n$-HEX and DCM extract contain a high concentration of fatty acids, with aromatic compounds as secondary components, while the aqueous extract contains mostly glycosides and the $\mathrm{MeOH}$ extract contains a variety of compounds, both free and linked to sugars.

In this report, we only include a detailed characterisation of compounds 3 and $\mathbf{4}$, since they have not been previously reported as natural compounds, only as synthesised compounds. For compounds 1 and 2, only a brief characterisation has been included since they have been fully described in previous works ( $\triangleright$ Fig. 1). 


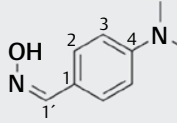

(1)

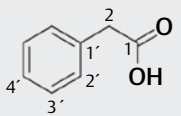

(2)

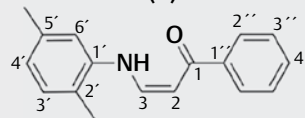

(3)

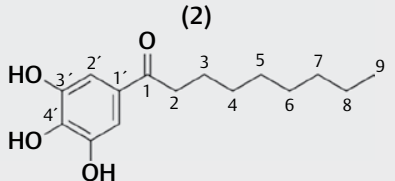

(4)
- Fig. 1 The chemical structures of compounds from S. mauritianum. (4-[(Z)-(Hydroxyimino)methyl]- $N, N$-dimethylaniline (1), phenylacetic acid (2), (2Z)-3-[(2,5-dimethylphenyl)amino]-1-phenyl2-propen-1-one (3), and 1-(3,4,5-trihydroxyphenyl)-1-nonanone (4).

Subsequently, a comparison was made between the ${ }^{1} \mathrm{H}$ NMR spectra of the DCM extract and those of the resulting compounds (Fig. 6S, Supporting Information). Given the low relative mass of the compounds compared to the original extract and the complexity of the extract, it was to be expected that the signals of the compounds tended to be weaker and less defined. Signals around $\delta_{\mathrm{H}}$ $7.2 \mathrm{ppm}$ were shown in both the extract and compounds $\mathbf{2 , 3}$, and 4. Signals around $\delta_{\mathrm{H}}$ 1.7-1.2 ppm in the DCM extract masked the aliphatic multiplets of compound 4 . Also, the signals of compound 1 were not easily distinguishable in the extract spectrum.

4-[(Z)-(Hydroxyimino)-methyl]-N,N-dimethylaniline (1) was obtained as a yellow solid; $R_{f}=0.35$ (HEX/AcOEt 9:1); m.p. $140{ }^{\circ} \mathrm{C} ; \geq 93 \%$ purity; ${ }^{1} \mathrm{H} N M R\left(500 \mathrm{MHz}, \mathrm{CD}_{3} \mathrm{OD}\right) \delta_{\mathrm{H}} 7.96(\mathrm{~s}, 1 \mathrm{H} / \mathrm{H}-1$ '), $7.40(\mathrm{dt}$, $J=8.8,1.9 \mathrm{~Hz}, 2 \mathrm{H} / \mathrm{H}-2), 6.70(\mathrm{dt}, J=9.0,3.0 \mathrm{~Hz}, 2 \mathrm{H} / \mathrm{H}-3), 2.94(\mathrm{~s}, 6 \mathrm{H} /$ $\left.\mathrm{NCH}_{3}\right) ;{ }^{13} \mathrm{C} \mathrm{NMR}\left(126 \mathrm{MHz}, \mathrm{CD}_{3} \mathrm{OD}\right) \delta_{\mathrm{C}} 152.93 / \mathrm{C}-4,150.98 / \mathrm{C}-1$ ', $129.00 / \mathrm{C}-2,121.85 / \mathrm{C}-1,113.17 / \mathrm{C}-3,40.45 / \mathrm{NCH}_{3}$; HR-ESI-MS $[\mathrm{M}+\mathrm{H}]^{+} \mathrm{m} / \mathrm{z}=165.1015$ and $[\mathrm{M}+\mathrm{Na}]^{+} \mathrm{m} / \mathrm{z}=187.0834$ (calculated for $\mathrm{C}_{9} \mathrm{H}_{13} \mathrm{~N}_{2} \mathrm{O}, 165.1022$ and $\left.\mathrm{C}_{9} \mathrm{H}_{12} \mathrm{~N}_{2} \mathrm{NaO}, 187.0842\right)$. The spectroscopic data obtained for compound $\mathbf{1}$ (Figs. 7S-13S and Table 1S, Supporting Information) were corroborated with the available literature references $[26,27]$.

Phenylacetic acid (2) was obtained as a white solid; $R_{f}=0.44$ (HEX/AcOEt 3:1); m.p. $76^{\circ} \mathrm{C} ; \geq 98 \%$ purity; ${ }^{1} \mathrm{H} N M R(300 \mathrm{MHz}$, $\left.\mathrm{CDCl}_{3}\right) \delta_{\mathrm{H}} 11.33(\mathrm{~s}, 1 \mathrm{H} / \mathrm{OH}), 7.37-7.18\left(\mathrm{~m}, 5 \mathrm{H} / \mathrm{H}^{2} 2^{\prime}, \mathrm{H}-3^{\prime}, \mathrm{H}-4^{\prime}\right)$, $3.61(\mathrm{~s}, 2 \mathrm{H} / \mathrm{H}-2) ;{ }^{13} \mathrm{C} \mathrm{NMR}\left(75 \mathrm{MHz} \mathrm{CDCl}_{3}\right) \delta_{\mathrm{C}} 178.25 / \mathrm{C}-1,133.37 /$ C-1', 129.51/C-3', 128.79/C-2', 127.50/C-4', 41.21/C-2; HR-ESI-MS 136.0522 (calculated for $\mathrm{C}_{8} \mathrm{H}_{8} \mathrm{O}_{2}, 136.0524$ ). The spectroscopic data obtained for compound $\mathbf{2}$ (Figs. 14S-20S and Table 2S, Supporting Information) were corroborated with the available literature references [28].

(Z)-3-((2,5-Dimethylphenyl)-amino)-1-phenylprop-2-en-1-one (3) was obtained as a white solid; $R_{f}=0.63$ (Hex/AcOEt, 2:1); m.p. $139{ }^{\circ} \mathrm{C}$; $\geq 99 \%$ purity (Figs. 21S-31S and Table 3S, Supporting Information). HR-ESI-MS yielded peaks for the protonated ion $\left([\mathrm{M}+\mathrm{H}]^{+} \mathrm{m} / \mathrm{z}=252.1373\right)$ and the sodium adduct $\left([\mathrm{M}+\mathrm{Na}]^{+} \mathrm{m} / \mathrm{z}=\right.$ 274.1194), accounting for a molecular formula of $\mathrm{C}_{17} \mathrm{H}_{17} \mathrm{NO}$, with a degree of unsaturation of ten.

The ${ }^{1} \mathrm{H}$ NMR spectrum showed a total of ten signals, with a signal at $\delta_{\mathrm{H}} 12.28,(1 \mathrm{H}, \mathrm{d}, J=12.1)$, corresponding to the NH exchangeable amine proton, two singlet signals at $\delta_{\mathrm{H}} 2.41$ and 2.35 , each in- tegrating for three protons, corresponding to two different methyl groups $\left(\mathrm{CH}_{3}-2^{\prime}\right.$ and $\left.\mathrm{CH}_{3}-5^{\prime}\right)$, and two signals at a shift of $\delta_{\mathrm{H}} 7.60$ $(1 \mathrm{H}, \mathrm{dd}, J=12.1,7.7)$ and $6.06(1 \mathrm{H}, \mathrm{d}, J=7.8)$, corresponding to an olefin fragment (protons $\mathrm{H}-3$ and $\mathrm{H}-2$ ). The aromatic region showed 5 signals, $7.10(1 \mathrm{H}, \mathrm{d}, J=7.6), 6.84(1 \mathrm{H}, \mathrm{dt}, J=7.6,1.1), 7.01$ $(1 \mathrm{H}, \mathrm{t}, J=1.0), 7.96(2 \mathrm{H}, \mathrm{dt}, J=6.2,1.5)$, and $7.55-7.39(3 \mathrm{H}, \mathrm{m})$, that were integrated for a total of 8 protons, indicating the existence of a monosubstituted phenyl and an asymmetrically trisubstituted phenyl. Finally, the analysis of the / coupling constants on protons $\mathrm{H}-2$ and $\mathrm{H}-3$ led to the conclusion that the corresponding isomer of this compound is the $(Z)$ isomer, as the $7 \mathrm{~Hz}$ value shown in both signals is characteristic of cis olefinic protons.

The ${ }^{13} \mathrm{C}$ NMR and DEPT-135 spectra showed the presence of fifteen distinct signals, corresponding to five quaternary carbon atoms, eight $\mathrm{CH}$ groups, and two $\mathrm{CH}_{3}$ groups. Signals $\delta_{\mathrm{C}} 127.3$ and 128.3 were found in greater intensity, thus supporting the hypothesis of the existence of a monosubstituted phenyl. Likewise, the presence of a signal at $\delta_{C} 191.0$ indicated the existence of a carbon$\mathrm{yl}$ group, and the signals at $\delta_{\mathrm{C}} 21.2$ and 17.2 confirmed the presence of two methyl groups.

The final assignment of the compound was done using the ${ }^{1} \mathrm{H}-{ }^{1} \mathrm{H}$ COSY, HSQC, and HMBC spectra ( Fig. 2). The ${ }^{1} \mathrm{H}-{ }^{1} \mathrm{H}$ COSY spectrum showed the presence of three independent spin systems, constituted by an olefin, a phenyl, and an aniline ring. The multiplicities of $\mathrm{H}-3^{\prime}, \mathrm{H}-4^{\prime}$, and $\mathrm{H}-6$ ' protons, and the appearance of weak ${ }^{1} \mathrm{H}-{ }^{1} \mathrm{H}$ COSY correlations between the pairs $\left(\mathrm{H}-2{ }^{\prime} \mathrm{CH}_{3}\right.$ with $\mathrm{H}-3$ ' and $\mathrm{H}-5$ ' $\mathrm{CH}_{3}$ with $\mathrm{H}-6$ ' and $\mathrm{H}-4$ ') allowed the placement of the methyl groups within the aniline ring. Finally, the information from the HMBC spectrum reinforced the proposed structure, showing two groups of main correlations. On the one hand, the olefin and phenyl systems showed correlations with the carbonyl group $(\mathrm{H}-2, \mathrm{H}-3, \mathrm{H}-1$ " $/ \mathrm{C}-1)$, while the $\mathrm{H}-3$ proton showed a correlation with $\mathrm{C}-1$ ', confirming the amine bond. On the other hand, the aniline ring showed an abundance of signals that were correlated to both the atoms forming the ring and those with the methyl groups. Each of these methyl groups showed three correlations, one strong $\left(\mathrm{H}-2^{\prime} \mathrm{CH}_{3} / \mathrm{C}-2^{\prime}\right.$ and $\left.\mathrm{H}-5^{\prime} \mathrm{CH}_{3} / \mathrm{C}-5^{\prime}\right)$ and two weaker ( $\mathrm{H}-2^{\prime} \mathrm{CH}_{3} / \mathrm{C}-1^{\prime}, \mathrm{C}-3^{\prime}$ ' and $\mathrm{H}-5^{\prime} \mathrm{CH}_{3} / \mathrm{C}-4^{\prime}, \mathrm{C}-6$ ').

1-(3,4,5-Trihydroxyphenyl)-nonan-1-one (4) was obtained as an amber solid; $R_{f}=0.44$ (Hex/AcOEt, 2:1); m.p. $156^{\circ} \mathrm{C} ; \geq 98 \%$ purity (Figs. 32S-40S and Table 4S, Supporting Information). HR-ESIMS yielded peaks for the protonated ion $\left([\mathrm{M}+\mathrm{H}]^{+} \mathrm{m} / \mathrm{z}=267.1584\right)$ and the sodium adduct $\left([\mathrm{M}+\mathrm{Na}]^{+} \mathrm{m} / \mathrm{z}=289.1404\right)$, accounting for a molecular formula of $\mathrm{C}_{15} \mathrm{H}_{22} \mathrm{O}_{4}$, with a degree of unsaturation of five.

The analysis of the ${ }^{1} \mathrm{H}$ NMR spectrum shows seven multiplets, with one aromatic singlet at $\delta_{H} 7.21$, which integrates for two protons, suggesting a symmetrical tetrasubstituted phenyl ring, and two broad singlets at $\delta_{H} 6.14$ and 5.89 , suggesting the existence of two different interchangeable protons (3'-OH and 4'-OH). Likewise, a triplet type signal $(2 \mathrm{H}, J=7.4)$ was found at $\delta_{\mathrm{H}} 2.88$, corresponding to $\mathrm{H}-2$ in position $\alpha$ with the carbonyl group, while the following signal, corresponding to a multiplet at $\delta_{H} 1.75-1.62$, was correlated with $\mathrm{H}-3$ in the $\beta$ position with the carbonyl group. In the shift between $\delta_{\mathrm{H}} 1.40-1.23$, there was a multiplet signal corresponding to the rest of the $\mathrm{CH}_{2}$ groups of the aliphatic chain. Finally, the last signal, a triplet at $\delta_{\mathrm{H}} 0.88(3 \mathrm{H}, J=7.0)$, was assigned to a terminal methyl group. 


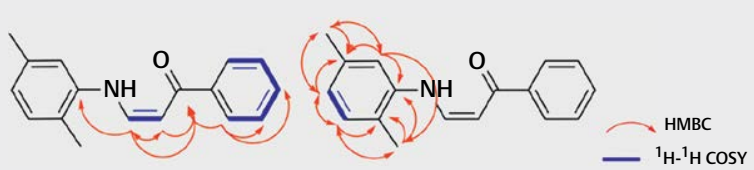

- Fig. 2 Structural correlation of compound 3.

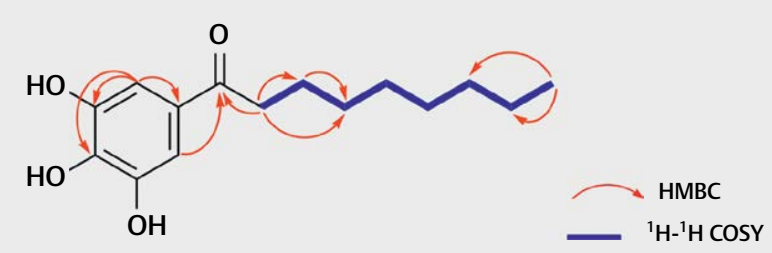

- Fig. 3 Structural correlation of compound 4.

The ${ }^{13} \mathrm{C}$ NMR and DEPT-135 spectra showed the presence of thirteen distinct signals, corresponding to four quaternary carbon atoms, a $\mathrm{CH}$ group, seven $\mathrm{CH}_{2}$ groups, and a $\mathrm{CH}_{3}$ group, signalling an aliphatic chain of eight carbon atoms. The signals at $\delta_{\mathrm{C}} 108.9$ and 143.7 that show a higher intensity reinforced the hypothesis of the symmetrically tetra-substituted phenyl. The signal at $\delta_{\mathrm{C}}$ 201.0 pointed to the existence of a carbonyl group, and the high shifts of the quaternary aromatic carbons (C-3' and C-4') pointed to the existence of a trihydroxy derivative. The shifts of carbons $\left(\delta_{C}\right.$ $29.5)$ and $C-6\left(\delta_{C} 29.5\right)$ appeared very close together due to their placement in the middle of the non-functionalised aliphatic chain, which implies similar chemical environments, and thus, chemical shifts due to the absence of any significant inductive effect.

The final compound assignment was performed with the data extracted from the ${ }^{1} \mathrm{H}-{ }^{1} \mathrm{H}$ COSY, HSQC, and HMBC spectra (• Fig. $\mathbf{3}$ ). The ${ }^{1} \mathrm{H}-{ }^{1} \mathrm{H}$ COSY spectrum was consistent with the assignment, no further information could be extracted from it, as the $\mathrm{CH}_{2}$ multiplet does not have the required resolution to differentiate between the individual alkyl protons. However, the HMBC spectrum showed correlations between the $\mathrm{H}-3 / \mathrm{C}-4, \mathrm{H}-9 / \mathrm{C}-7$, and $\mathrm{H}-9 / \mathrm{C}-8$ pairs, which allowed their assignment. There were also signals that correlated $\mathrm{H}-2$ ' with the rest of the aromatic carbons in addition to the carbonyl group.

Regarding the cytotoxicity of the $S$. mauritianum extracts, the results showed that the $D C M\left(C C_{50}=95.30-97.20 \mu \mathrm{g} / \mathrm{mL}\right)$ and aqueous $\left(\mathrm{CC}_{50}=95.34-96.67 \mu \mathrm{g} / \mathrm{mL}\right)$ extracts did not show relevant $c y-$ totoxicity $(p=0.089)$ when compared to the actinomycin $D(A C T)$ positive control $\left(\mathrm{CC}_{50}=0.01 \mu \mathrm{g} / \mathrm{mL}\right)$ in any of the cell lines $(C 8 D 1 A$, Neuro-2a, and EOC 13.31) ( Table 1).

Concerning the anti-inflammatory capacity, the results showed that the $\mathrm{MeOH}\left(\mathrm{IC}_{50}=22.35-25.73 \mu \mathrm{g} / \mathrm{mL}\right)$ extract presented a higher inhibitory activity of the production of NF- $\kappa$ B than the DCM extract $\left(\mathrm{IC}_{50}=26.15-27.65 \mu \mathrm{g} / \mathrm{mL}\right.$ ) (compared to the positive control, celastrol, $I_{50}=3.34 \mu \mathrm{g} / \mathrm{mL}$ ) ( $\triangleright$ Table 2). However, the $\mathrm{MeOH}$ extract did show cytotoxicity in any of the tested cell lines.
- Table $1 \mathrm{CC}_{50}$ values of the XTT (cytotoxicity) assays, calculated for the extracts from S. mauritianum. $\mathrm{CC}_{50}$ values were calculated using Prism v9.0.0 (GraphPad Software) using nonlinear regression, dose-response curves.

\begin{tabular}{|c|c|c|c|}
\hline \multirow[t]{2}{*}{ Extracts } & \multicolumn{3}{|c|}{ Cytotoxicity $\left(\mathrm{CC}_{50} \mu \mathrm{g} / \mathrm{mL}\right)$ at $72 \mathrm{~h}(\mathrm{Cl} 95 \%, \mathrm{R} 2)$} \\
\hline & C8D1A & Neuro-2a & EOC 13.31 \\
\hline $\begin{array}{l}\text { Untreated } \\
\text { cells }\end{array}$ & $\begin{array}{l}98.23(93.95 \text { to } \\
103.55,0.9723)\end{array}$ & $\begin{array}{l}98.61(93.20 \text { to } \\
103.80,0.9896) \\
\end{array}$ & $\begin{array}{l}98.92(93.94 \text { to } \\
103.75,0.9947) \\
\end{array}$ \\
\hline DMSO & $\begin{array}{l}20.28(15.02 \text { to } \\
25.19,0.9682)\end{array}$ & $\begin{array}{l}20.29(15.24 \text { to } \\
25.25,0.9766)\end{array}$ & $\begin{array}{l}20.58(15.45 \text { to } \\
25.52,0.9684)\end{array}$ \\
\hline ACT & $\begin{array}{l}0.01(-3.384 \text { to } \\
3.358,0.9192)\end{array}$ & $\begin{array}{l}0.01(-3.319 \text { to } \\
3.332,0.9422)\end{array}$ & $\begin{array}{l}0.01(-3.310 \text { to } \\
3.396,0.9574)\end{array}$ \\
\hline EHEX & $\begin{array}{l}85.66(80.55 \text { to } \\
90.38,0.9382)\end{array}$ & $\begin{array}{l}86.06(81.13 \text { to } \\
91.23,0.9643)\end{array}$ & $\begin{array}{l}86.42(81.38 \text { to } \\
91.40,0.9425)\end{array}$ \\
\hline EDCM & $\begin{array}{l}95.30(90.68 \text { to } \\
100.73,0.9355)\end{array}$ & $\begin{array}{l}96.52(91.61 \text { to } \\
101.57,0.9271)\end{array}$ & $\begin{array}{l}97.20(92.39 \text { to } \\
102.55,0.9702)\end{array}$ \\
\hline $\mathrm{EMeOH}$ & $\begin{array}{l}75.35 \text { (70.32 to } \\
80.95,0.9245)\end{array}$ & $\begin{array}{l}77.54 \text { (72.55 to } \\
82.89,0.9153)\end{array}$ & $\begin{array}{l}77.99(72.31 \text { to } \\
82.63,0.9622)\end{array}$ \\
\hline $\mathrm{EDH}_{2} \mathrm{O}$ & $\begin{array}{l}95.34(90.14 \text { to } \\
100.18,0.9441)\end{array}$ & $\begin{array}{l}96.56(91.33 \text { to } \\
101.99,0.9577)\end{array}$ & $\begin{array}{l}96.67 \text { (91.37 to } \\
101.21,0.9915)\end{array}$ \\
\hline \multicolumn{4}{|c|}{$\begin{array}{l}\mathrm{Cl} 95 \% \text { : confidence interval } 95 \% / \text { Tukey's multiple comparisons test } \\
\left({ }^{* * *} \mathrm{p}<0.001\right) . \mathrm{ACT}=\text { actinomycin } \mathrm{D}, \mathrm{EHEX}=n \text {-hexane extract, } \\
\mathrm{EDCM}=\text { dichloromethane extract, } \mathrm{EMeOH}=\text { methanol extract, } \\
\mathrm{EDH}_{2} \mathrm{O}=\text { aqueous extract. }\end{array}$} \\
\hline
\end{tabular}

Regarding the ability to inhibit AChE by S. mauritianum extracts, only the DCM extract inhibited AChE by $53.30 \%\left(\mathrm{IC}_{50}=26.94 \mu \mathrm{g} /\right.$ $\mathrm{mL}$ ) compared to galantamine (positive control), which inhibits it by $90.38 \%\left(\mathrm{IC}_{50}=4.31 \mu \mathrm{g} / \mathrm{mL}\right)$ ( Fig. 4$)$.

On the other hand, regarding the inhibition of $A \beta$ aggregation by the extracts of $S$. mauritianum, only the DCM extract showed an inhibition of the $A \beta$ aggregation by $59.02 \%\left(I C_{50}=26.94 \mu \mathrm{g} / \mathrm{mL}\right)$ compared to curcumin (positive control), which inhibits it by $71.19 \%\left(\mathrm{IC}_{50}=3.68 \mu \mathrm{g} / \mathrm{mL}\right)$ ( Fig. 5).

The DCM extract was fractionated using HEX/AcOEt as the mobile phase, producing eight fractions that were subjected to cytotoxicity, anti-inflammatory, and anti-Alzheimer's assays. Table $\mathbf{5 S}$ shows the cytotoxicity results; fractions F1-F6 showed low cytotoxicity while the last fractions (F7 and F8) were highly cytotoxic. The anti-inflammatory results showed that fractions $\mathbf{F 2}$ $\left(I C_{50}=14.99-15.94 \mu \mathrm{g} / \mathrm{mL}\right), \mathbf{F 4}\left(\mathrm{IC}_{50}=15.28-15.79 \mu \mathrm{g} / \mathrm{mL}\right)$, and F5 $\left(\mathrm{IC}_{50}=12.27-12.56 \mu \mathrm{g} / \mathrm{mL}\right)$ have the highest inhibitory activity of NF- $\kappa$ B production (Table 6S, Supporting Information). Concerning the anti-Alzheimer's activity of the fractions obtained from the DCM extract, the results showed that fractions $\mathbf{F} 2\left(\mathrm{IC}_{50}=15.57 \mu \mathrm{g} /\right.$ $\mathrm{mL})$, F4 $\left(\mathrm{IC}_{50}=15.51 \mu \mathrm{g} / \mathrm{mL}\right)$, and $\mathbf{F 5}\left(\mathrm{IC}_{50}=12.37 \mu \mathrm{g} / \mathrm{mL}\right)$ inhibit AChE by $55.46,59.70$, and $56.61 \%$, respectively, compared to galantamine, which inhibits it by $90.38 \%\left(\mathrm{IC}_{50}=4.31 \mu \mathrm{g} / \mathrm{mL}\right)$ (Fig. 41S, Supporting Information). Additionally, the results on the inhibition of $A \beta$ aggregation confirmed that fractions $F 2\left(I C_{50}=15.57 \mu \mathrm{g} / \mathrm{mL}\right)$, F4 $\left(\mathrm{IC}_{50}=15.51 \mu \mathrm{g} / \mathrm{mL}\right)$, and F5 $\left(\mathrm{IC}_{50}=12.37 \mu \mathrm{g} / \mathrm{mL}\right)$ have inhibition percentages of $60.51,60.59$, and $64.83 \%$, respectively, while curcumin has an inhibition rate of $71.19 \%\left(\mathrm{IC}_{50}=3.68 \mu \mathrm{g} / \mathrm{mL}\right)$ (Fig. 42S, Supporting Information).

A total of four subfractions (F2A-F2D) were obtained through the chromatographic separation of fraction $\mathbf{F} 2$, which were subsequently tested through cytotoxicity, anti-inflammatory and anti- 
- Table $2 \mathrm{IC}_{50}$ values of the inhibition of NF- $\kappa$ B production, calculated for the extracts from $S$. mauritianum. $I C_{50}$ values were calculated using Prism v9.0.0 (GraphPad Software) using nonlinear regression, dose-response curves.

\begin{tabular}{|c|c|c|c|}
\hline \multirow[t]{2}{*}{ Extracts } & \multicolumn{3}{|c|}{$\begin{array}{l}\text { Inhibition of NF- } \kappa \text { B production }\left(\mathrm{IC}_{50} \mu \mathrm{g} / \mathrm{mL}\right) \text { at } 72 \mathrm{~h}(\mathrm{Cl} \\
95 \%, \mathrm{R} 2)\end{array}$} \\
\hline & C8D1A & Neuro-2a & EOC 13.31 \\
\hline $\begin{array}{l}\text { Untreated } \\
\text { cells }\end{array}$ & $\begin{array}{l}16.76(11.30 \text { to } \\
21.08,0.9521)\end{array}$ & $\begin{array}{l}18.46(13.18 \text { to } \\
23.74,0.9584)\end{array}$ & $\begin{array}{l}18.73(13.16 \text { to } \\
23.75,0.9930)\end{array}$ \\
\hline Celastrol & $\begin{array}{l}3.34(-2.38 \text { to } \\
8.06,0.9499)\end{array}$ & $\begin{array}{l}3.34(-2.07 \text { to } \\
8.62,0.9416)\end{array}$ & $\begin{array}{l}3.34(-2.65 \text { to } \\
8.70,0.9442)\end{array}$ \\
\hline EHEX & $\begin{array}{l}36.83(31.08 \text { to } \\
41.85,0.9457)\end{array}$ & $\begin{array}{l}38.12(33.13 \text { to } \\
43.46,0.9579)\end{array}$ & $\begin{array}{l}39.68(34.63 \text { to } \\
44.40,0.9982)\end{array}$ \\
\hline EDCM & $\begin{array}{l}26.15(21.21 \text { to } \\
31.21,0.9542)\end{array}$ & $\begin{array}{l}27.03(22.83 \text { to } \\
32.95,0.9637)\end{array}$ & $\begin{array}{l}27.65(22.24 \text { to } \\
32.27,0.9427)\end{array}$ \\
\hline $\mathrm{EMeOH}$ & $\begin{array}{l}22.35(17.64 \text { to } \\
27.15,0.9932)\end{array}$ & $\begin{array}{l}23.91(18.28 \text { to } \\
28.72,0.9687)\end{array}$ & $\begin{array}{l}25.73(20.70 \text { to } \\
30.30,0.9454)\end{array}$ \\
\hline $\mathrm{EDH}_{2} \mathrm{O}$ & $\begin{array}{l}90.53(85.41 \text { to } \\
95.79,0.9666)\end{array}$ & $\begin{array}{l}90.82(85.62 \text { to } \\
95.39,0.9658)\end{array}$ & $\begin{array}{l}93.34(88.23 \text { to } \\
98.18,0.9455)\end{array}$ \\
\hline \multicolumn{4}{|c|}{$\begin{array}{l}\mathrm{Cl} 95 \% \text { : confidence interval } 95 \% / \text { Tukey's multiple comparisons test } \\
\left({ }^{* * *} \mathrm{P}<0.001\right) \text {; } \mathrm{EHEX}=n \text {-hexane extract, } \mathrm{EDCM}=\text { dichloromethane } \\
\text { extract, } \mathrm{EMeOH}=\text { methanol extract, } \mathrm{EDH}_{2} \mathrm{O}=\text { aqueous extract. }\end{array}$} \\
\hline
\end{tabular}

Alzheimer's assays. Table 7S, Supporting Information, shows the cytotoxicity results; subfractions F2A and F2B showed low cytotoxicity when compared to the others subfractions. The anti-inflammatory results showed that subfraction F2B $\left(\mathrm{IC}_{50}=9.06-\right.$ $9.93 \mu \mathrm{g} / \mathrm{mL}$ ) has the highest inhibitory activity of NF- $\kappa$ B production (Table 8S, Supporting Information). Concerning anti-Alzheimer's activity of the subfractions, the results showed that subfraction F2B $\left(\mathrm{IC}_{50}=9.47 \mu \mathrm{g} / \mathrm{mL}\right)$ inhibits AChE by $64.76 \%$ compared to galantamine, which inhibits it by $90.38 \%\left(\mathrm{IC}_{50}=4.31 \mu \mathrm{g} / \mathrm{mL}\right)$ (Fig. 43S, Supporting Information). Additionally, the results on the inhibition of $A \beta$ aggregation confirmed that subfraction $\mathbf{F} 2 B\left(I_{50}=9.47 \mu \mathrm{g} /\right.$ $\mathrm{mL}$ ) has an inhibition percentage of $66.51 \%$, while curcumin has an inhibition rate of $71.19 \%\left(\mathrm{IC}_{50}=3.68 \mu \mathrm{g} / \mathrm{mL}\right)$ (Fig. 44S, Supporting Information).

A total of five subfractions (F4A-F4E) were obtained through the chromatographic separation of fraction $\mathbf{F 4}$, which were subsequently tested through cytotoxicity, anti-inflammatory, and antiAlzheimer's assays. Table 9S, Supporting Information, shows the cytotoxicity results; subfractions F4A and F4B showed low cytotoxicity when compared to the others subfractions. The anti-inflammatory results showed that subfraction $\mathbf{F 4 B}\left(\mathrm{IC}_{50}=13.26-\right.$ $13.65 \mu \mathrm{g} / \mathrm{mL}$ ) has the highest inhibitory activity of NF- $\mathrm{KB}$ production (Table 10S, Supporting Information). Concerning the anti-Alzheimer's activity of the subfractions, the results showed that subfraction F4B $\left(\mathrm{IC}_{50}=13.46 \mu \mathrm{g} / \mathrm{mL}\right)$ inhibits AChE by $66.87 \%$ compared to galantamine, which has an inhibition rate of $90.38 \%$ $\left(\mathrm{IC}_{50}=4.31 \mu \mathrm{g} / \mathrm{mL}\right)$ (Fig. 45S, Supporting Information). Additionally, the results on the inhibition of $A \beta$ aggregation confirmed that subfraction $\mathbf{F} 4 \mathbf{B}\left(\mathrm{IC}_{50}=13.46 \mu \mathrm{g} / \mathrm{mL}\right)$ has an inhibition percentage of $69.26 \%$, while curcumin has an inhibition rate of $71.19 \%$ $\left(\mathrm{IC}_{50}=3.68 \mu \mathrm{g} / \mathrm{mL}\right)$ (Fig. 46S, Supporting Information).

A total of four subfractions (F5A-F5D) were obtained through the chromatographic separation of fraction $\mathbf{F 5}$, which were subse-

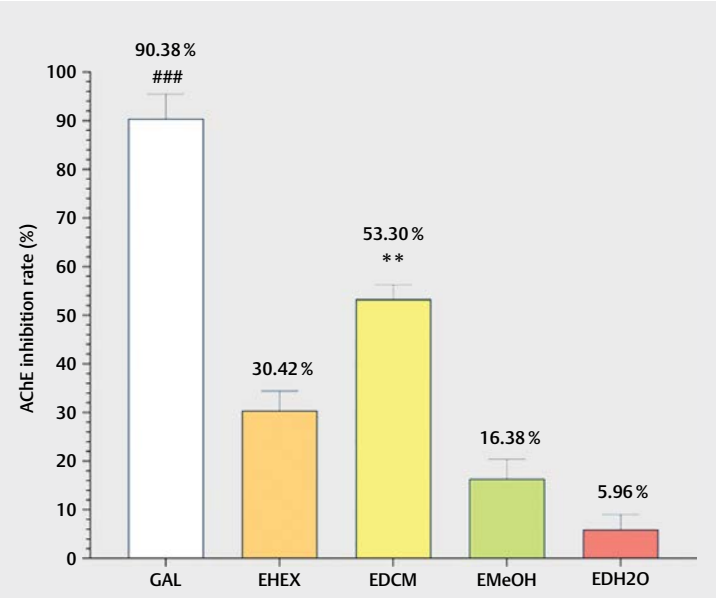

$\mathrm{GAL}=$ galantamine $\left(\mathrm{IC}_{50}=4.31 \mathrm{\mu g} / \mathrm{mL}\right)$; $E H E X=n$-hexane extract

$\left(\mathrm{IC}_{50}=38.21 \mu \mathrm{g} / \mathrm{mL}\right) ; \mathrm{EDCM}=$ dichloromethane extract

$\left(\mathrm{IC}_{50}=26.94 \mu \mathrm{g} / \mathrm{mL}\right), \mathrm{EMeOH}=$ methanol extract

$\left(\mathrm{IC}_{50}=24.00 \mu \mathrm{g} / \mathrm{mL}\right) ; \mathrm{EHD}_{2} \mathrm{O}=$ aqueous extract

$\left(I C_{50}=91.56 \mu \mathrm{g} / \mathrm{mL}\right)$

- Fig. 4 Effect of extracts from S. mauritianum on in vitro AChE inhibition. AChE inhibitory activity is expressed as \% inhibition. Values are expressed as the mean \pm SEM, $n=3$ for each concentration ( $\mathrm{I}_{50}$ obtained from the NF- $\mathrm{KB}$ inhibition assay).

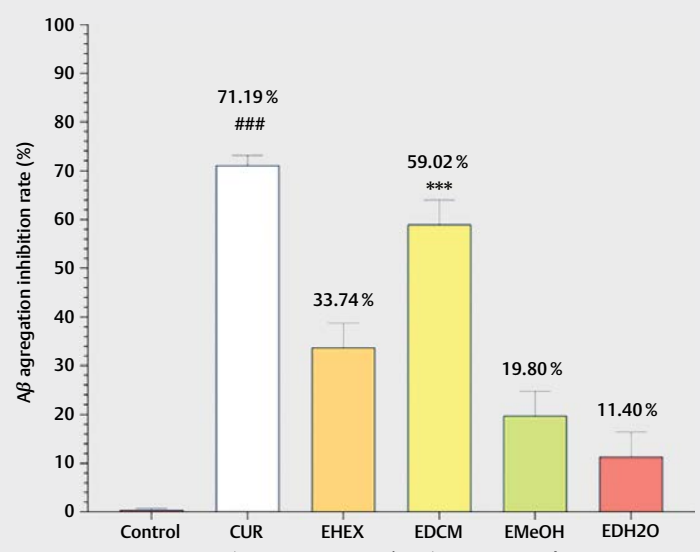

CUR=curcumin $\left(I_{50}=3.68 \mu \mathrm{g} / \mathrm{mL}\right)$; EHEX=n-hexane extract $\left(\mathrm{IC}_{50}=38.21 \mu \mathrm{g} / \mathrm{mL}\right) ; \mathrm{EDCM}=$ dichloromethane extract $\left(\mathrm{IC}_{50}=26.94 \mu \mathrm{g} / \mathrm{mL}\right)$, EMeOH=methanol extract $\left(\mathrm{IC}_{50}=24.00 \mu \mathrm{g} / \mathrm{mL}\right) ; \mathrm{EHD}_{2} \mathrm{O}=$ aqueous extract $\left(I C_{50}=91.56 \mu \mathrm{g} / \mathrm{mL}\right)$

- Fig. 5 The $A \beta$ aggregation inhibition activity of tested extracts from S. mauritianum after $72 \mathrm{~h}$ incubation.

quently tested through cytotoxicity, anti-inflammatory, and antiAlzheimer's assays. Table 11S, Supporting Information, shows the cytotoxicity results; subfractions F5B and F5C showed low cytotoxicity when compared to the others subfractions. The anti-inflammatory results showed that subfraction $\mathbf{F 5 C}\left(\mathrm{IC}_{50}=6.81-\right.$ $7.02 \mu \mathrm{g} / \mathrm{mL}$ ) has the highest inhibitory activity of NF- $\kappa$ B production 
- Table $3 \mathrm{CC}_{50}$ values of the XTT (cytotoxicity) assays, calculated for the compounds from $S$. mauritianum. $\mathrm{CC}_{50}$ values were calculated using Prism v9.0.0 (GraphPad Software) using nonlinear regression, dose-response curves.

\begin{tabular}{|c|c|c|c|}
\hline \multirow[t]{2}{*}{ Samples } & \multicolumn{3}{|c|}{ Cytotoxicity $\left(\mathrm{CC}_{50} \mu \mathrm{M}\right)$ at $72 \mathrm{~h}(\mathrm{Cl} 95 \%, \mathrm{R} 2)$} \\
\hline & C8D1A & Neuro-2a & EOC 13.31 \\
\hline Untreated cells & $\begin{array}{l}98.48 \text { (93.93 to } \\
103.15 \\
0.9424)\end{array}$ & $\begin{array}{l}98.23(93.28 \\
\text { to } 103.35 \\
0.9778)\end{array}$ & $\begin{array}{l}98.93(93.94 \\
\text { to } 103.85 \\
0.9728)\end{array}$ \\
\hline DMSO & $\begin{array}{l}10.05 \text { (5.86 to } \\
15.41,0.9649)\end{array}$ & $\begin{array}{l}10.07(5.38 \text { to } \\
15.56,0.9807)\end{array}$ & $\begin{array}{l}10.08 \text { (5.64 to } \\
15.81,0.9998)\end{array}$ \\
\hline ACT & $\begin{array}{l}0.008(-4.172 \\
\text { to } 4.120 \\
0.9955)\end{array}$ & $\begin{array}{l}0.008(-4.156 \\
\text { to } 4.192, \\
0.9998)\end{array}$ & $\begin{array}{l}0.008(-4.132 \\
\text { to } 4.123, \\
0.9454)\end{array}$ \\
\hline Compound 1 & $\begin{array}{l}86.63 \text { (81.45 to } \\
91.94,0.9605)\end{array}$ & $\begin{array}{l}88.08(83.90 \\
\text { to } 93.74 \text {, } \\
0.9498)\end{array}$ & $\begin{array}{l}88.93(83.64 \\
\text { to } 93.12 \text {, } \\
0.9928)\end{array}$ \\
\hline Compound 2 & $\begin{array}{l}93.56(88.56 \text { to } \\
98.30,0.9652)\end{array}$ & $\begin{array}{l}94.33(89.16 \\
\text { to } 99.43 \text {, } \\
0.9873)\end{array}$ & $\begin{array}{l}96.15(91.13 \\
\text { to } 101.05 \text {, } \\
0.9895)\end{array}$ \\
\hline Compound 3 & $\begin{array}{l}71.25 \text { (66.16 to } \\
76.85,0.9913)\end{array}$ & $\begin{array}{l}71.37(66.79 \\
\text { to } 76.52 \\
0.9563)\end{array}$ & $\begin{array}{l}71.65(66.70 \\
\text { to } 76.19, \\
0.9313)\end{array}$ \\
\hline Compound 4 & $\begin{array}{l}69.41 \text { (64.01 to } \\
74.80,0.9718)\end{array}$ & $\begin{array}{l}70.54(65.32 \\
\text { to } 75.73 \text {, } \\
0.9639)\end{array}$ & $\begin{array}{l}70.95(65.17 \\
\text { to } 75.44 \text {, } \\
0.9492)\end{array}$ \\
\hline $\begin{array}{l}\text { Cl 95\%: confid } \\
\left({ }^{* * *} p<0.001\right) ;\end{array}$ & $\begin{array}{l}\text { rval 95\%/Tuke) } \\
\text { tinomycin D }\end{array}$ & multinlo & sons test \\
\hline
\end{tabular}

(Table 12S, Supporting Information). Concerning the anti-Alzheimer's activity of the subfractions, the results showed that subfraction F5C $\left(\mathrm{IC}_{50}=6.91 \mu \mathrm{g} / \mathrm{mL}\right)$ inhibits AChE by $62.83 \%$ compared to galantamine, which has an inhibition rate of $90.38 \%\left(\mathrm{IC}_{50}=4.31 \mu \mathrm{g} /\right.$ $\mathrm{mL}$ ) (Fig. 47S, Supporting Information). Additionally, the results on the inhibition of $A \beta$ aggregation confirmed that subfraction $\mathbf{F 5 C}$ $\left(\mathrm{IC}_{50}=6.91 \mu \mathrm{g} / \mathrm{mL}\right)$ has an inhibition percentage of $65.04 \%$ compared to curcumin, which has an inhibition percentage of $71.19 \%$ $\left(\mathrm{IC}_{50}=3.68 \mu \mathrm{g} / \mathrm{mL}\right)$ (Fig. 48S, Supporting Information).

Table 3 shows the cytotoxicity of the pure compounds. Phenylacetic acid (compound 2, $C_{50}=93.56-96.15 \mu \mathrm{M}$ ) and 4-[(Z)(hydroxyimino)-methyl]-N,N-dimethylaniline (compound $\mathbf{1}$, $\left.\mathrm{CC}_{50}=86.63-88.93 \mu \mathrm{M}\right)$ had lower cytotoxicity than the compounds (Z)-3-((2,5-dimethylphenyl)-amino)-1-phenylprop-2-en-1-one (compound $\left.3, C_{50}=71.25-71.65 \mu \mathrm{M}\right)$ and 1-(3,4,5-trihydroxyphenyl)-nonan-1-one (compound 4, $\left.\mathrm{CC}_{50}=69.41-70.95 \mu \mathrm{M}\right)$.

Two of the four compounds showed an inhibitory capacity of $N F-\kappa B$ production higher than celastrol $\left(I_{50}=7.41 \mu \mathrm{M}\right)$, with $I C_{50}$ values of 1.59-1.93 $\mu \mathrm{M}$ (compound 4) and 2.41-2.79 $\mu \mathrm{M}$ (compound 3 ), while the other two had a smaller inhibitory capacity than the control, with values of 9.13-9.96 $\mathrm{M}$ (compound 1) and 17.17-17.77 $\mu \mathrm{M}$ (compound 2) ( Table 4).

Concerning anti-Alzheimer's activity of the compounds, the results showed that compound $\mathbf{4}\left(\mathrm{IC}_{50}=1.74 \mu \mathrm{M}\right)$ inhibited AChE by $83.32 \%$ compared to galantamine with an inhibitory capacity of $90.38 \%\left(I C_{50}=11.70 \mu \mathrm{M}\right)$ ( Fig. 6).
- Table $4 \quad I_{50}$ values of the inhibition of NF- $K B$ production, calculated for the compounds from $S$. mauritianum. $I C_{50}$ values were calculated using Prism v9.0.0 (GraphPad Software) using nonlinear regression, dose-response curves.

\begin{tabular}{|c|c|c|c|}
\hline \multirow[t]{2}{*}{ Samples } & \multicolumn{3}{|c|}{$\begin{array}{l}\text { Inhibition of NF- } \kappa \text { B production }\left(\mathrm{IC}_{50} \mu \mathrm{M}\right) \text { at } 72 \mathrm{~h} \\
(\mathrm{Cl} 95 \%, \mathrm{R} 2)\end{array}$} \\
\hline & C8D1A & Neuro-2a & EOC 13.31 \\
\hline Untreated cells & $\begin{array}{l}16.24(11.60 \text { to } \\
21.07,0.9868)\end{array}$ & $\begin{array}{l}18.56(13.80 \text { to } \\
23.18,0.9425)\end{array}$ & $\begin{array}{l}18.86(13.20 \text { to } \\
23.58,0.9774)\end{array}$ \\
\hline Celastrol & $\begin{array}{l}7.41(2.67 \text { to } \\
12.96,0.9513)\end{array}$ & $\begin{array}{l}7.43(2.44 \text { to } \\
12.46,0.9558)\end{array}$ & $\begin{array}{l}7.48(2.88 \text { to } \\
12.38,0.9526)\end{array}$ \\
\hline Compound 1 & $\begin{array}{l}9.13(4.48 \text { to } \\
14.51,0.9676)\end{array}$ & $\begin{array}{l}9.91(4.86 \text { to } \\
14.83,0.9967)\end{array}$ & $\begin{array}{l}9.96(4.57 \text { to } \\
14.40,0.9642)\end{array}$ \\
\hline Compound 2 & $\begin{array}{l}17.17(12.44 \text { to } \\
22.89,0.9554)\end{array}$ & $\begin{array}{l}17.30(12.04 \text { to } \\
22.85,0.9962)\end{array}$ & $\begin{array}{l}17.77(12.13 \text { to } \\
22.54,0.9659)\end{array}$ \\
\hline Compound 3 & $\begin{array}{l}2.41(-3.94 \text { to } \\
6.41,0.9802)\end{array}$ & $\begin{array}{l}2.65(-3.04 \text { to } \\
6.67,0.9439)\end{array}$ & $\begin{array}{l}2.79(-3.51 \text { to } \\
6.08,0.9967)\end{array}$ \\
\hline Compound 4 & $\begin{array}{l}1.59(-4.70 \text { to } \\
6.82,0.9878)\end{array}$ & $\begin{array}{l}1.69(-4.45 \text { to } \\
6.43,0.9518)\end{array}$ & $\begin{array}{l}1.93(-4.74 \text { to } \\
6.78,0.9658)\end{array}$ \\
\hline \multicolumn{4}{|c|}{$\begin{array}{l}\text { Cl } 95 \% \text { : confidence interval } 95 \% / \text { Tukey's multiple comparisons test } \\
\left({ }^{* * *} \mathrm{p}<0.001\right) .\end{array}$} \\
\hline
\end{tabular}

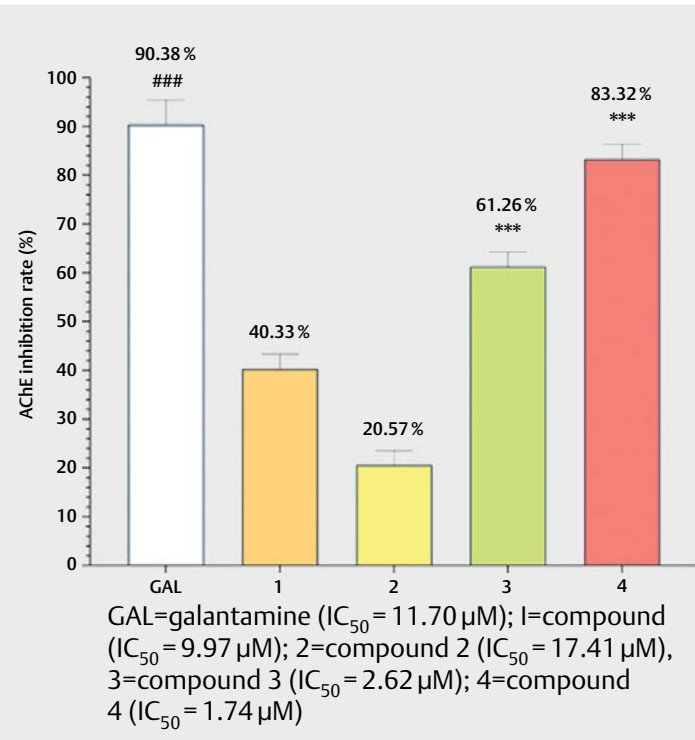

- Fig. 6 Effect of compounds from S. mauritianum on in vitro AChE inhibition. AChE inhibitory activity is expressed as \% inhibition. Values are expressed as the mean \pm SEM, $n=3$ for each concentration (IC 50 obtained from the NF- $K B$ inhibition assay).

Additionally, the results on the inhibition of $A \beta$ aggregation confirmed that compound $\mathbf{4}\left(\mathrm{IC}_{50}=1.74 \mu \mathrm{M}\right)$ has an inhibition percentage of $93 \%$ compared to curcumin, which has an inhibition percentage $71.19 \%\left(\mathrm{IC}_{50}=10 \mu \mathrm{M}\right)$ ( Fig. 7).

Regarding the cytotoxicity of the $S$. mauritianum, an aqueous extract enriched in saponins showed cytotoxicity at a concentration of $67.02 \pm 1.32$ and $304.08 \pm 0.47 \mu \mathrm{g} / \mathrm{mL}$ in the MCF-7 and HCT116 cell lines, respectively [29]. In addition, Jayakumar and Murugan [25] indicated in their study that extracts rich in alkaloids 


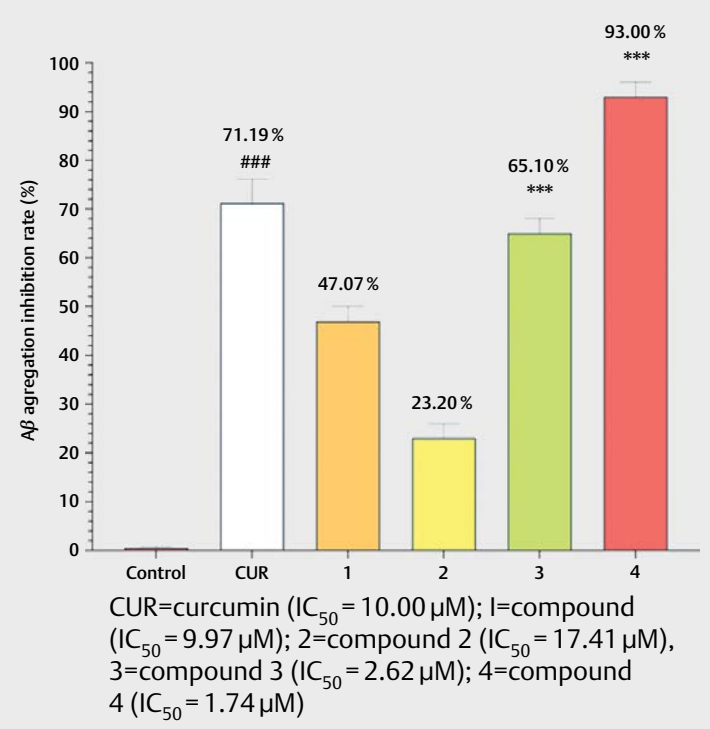

Fig. 7 The $A \beta$ aggregation inhibition activity of tested compounds from $S$. mauritianum after $72 \mathrm{~h}$ incubation.

showed cytotoxic activity, reporting that solasodine isolated from $\mathrm{CHCl}_{3} / \mathrm{AcOEt}_{\text {(6:4) }}$ showed cytotoxicity in MCF-7 cells, with $\mathrm{IC}_{50}$ values of $24.8,47.3$, and $87.4 \mu \mathrm{g} / \mathrm{mL}$ at 72,48 , and $24 \mathrm{~h}$ respectively, whereas, caulophillumine-A (C-A), isolated from the chloroform extract, had values of 35.6 (72 h), 54.1 (48 h), and $88.3 \mu \mathrm{g} / \mathrm{mL}$ (24h). However, our results show that the $\mathrm{IC}_{50}$ (cytotoxicity) values of the obtained extracts ( $\mathrm{HEX}, \mathrm{DCM}, \mathrm{MeOH}$, and $\mathrm{DH}_{2} \mathrm{O}$ ) are in the range of $85.66-96.67 \mu \mathrm{g} / \mathrm{mL}$ at $72 \mathrm{~h}$ of treatment in the $\mathrm{C} 8 \mathrm{D} 1 \mathrm{~A}$, Neuro-2a and EOC 13.31 cell lines. Analysing the differences in the cytotoxicity values, we can conclude that the composition of the extracts influences their cytotoxic activity, with the extracts rich in alkaloids being the most cytotoxic, followed by those rich in saponins and finally those extracts rich in polyphenolic compounds, which have the lowest cytotoxicity, thus confirming the analysis of our extracts from which polyphenolic compounds were isolated while presenting low cytotoxicity (Figs. 1S-5S, Supporting Information).

On the other hand, there are no reported studies related to the anti-inflammatory activity of S. mauritianum extracts. However, there are reports on the anti-inflammatory in vivo (murine model) activity of species of the genus Solanum, for example, the $\mathrm{MeOH}$ extract of S. nigrum showed activity at a dose of $375 \mathrm{mg} / \mathrm{kg}$ b.w. [30], the hydroethanol extract of Solanum lycocarpum exhibited in vivo activity at the dose of $75-150 \mathrm{mg} / \mathrm{kg}$ b.w. in the later phase of inflammation [31], and the n-HEX and chloroform extracts of Solanum pubescens showed activity at a dose of $200 \mathrm{mg} / \mathrm{kg}$ b.w. [32]. These results suggest that extracts of the species $S$. mauritianum have anti-inflammatory potential.

Finally, although there are no reports on S. mauritianum and its effect against $A D$, there are reports on extracts of Solanum gilo, Solanum kumba, and Solanum aethiopicum that modulate the activities of enzymes in purinergic, monoaminergic, and cholinergic systems associated with $\mathrm{AD}$-like symptoms, with an $\mathrm{IC}_{50}$ between
$10-15 \mu \mathrm{g} / \mathrm{mL}$ [33]. Reports on the ethanol extract from S. betaceum show a positive effect in the cognitive function of rats fed with doses between $100-400 \mathrm{mg} / \mathrm{kg}$ b.w., causing a decrease of levels of the $\mathrm{N}$-methyl-D-aspartate receptor [20]. Moreover, there are reports on the $\mathrm{MeOH}$ extract of Solanum virginianum showing memory-enhancing effects on rats fed with doses between $25-100 \mathrm{mg} /$ $\mathrm{kg}$ b.w. This effect can be partly attributed to the AChE inhibition, with an $\mathrm{IC}_{50}$ of $386.25 \mu \mathrm{g} / \mathrm{mL}$ [34]. In this sense, we can conclude that the extracts of $S$. mauritianum have potential against $A D$ as confirmed by previous reports on these related plants.

The four isolated compounds have been described in previous works. In relation to compound $\mathbf{1}$ (4-[(Z)-(hydroxyimino)-methyl]$N, N$-dimethylaniline), it has been synthetically obtained from hydroxyamine hydrochloride and 4-(dimethylamino)-benzaldehyde [35]. Compound $\mathbf{2}$ (phenylacetic acid) is an intermediate compound of the shikimic acid pathway present in plant species $[28,36]$. Regarding compound 3 ((Z)-3-((2,5-dimethylphenyl)amino)-1-phenylprop-2-en-1-one), it was obtained synthetically from (Z)-3-(dimethylamino)-1-phenylprop-2-en-1-one and 2,5-dimethylaniline [37]. Finally, compound 4(1-(3,4,5-trihydroxyphenyl)nonan-1-one) is a derivative of gallic acid, previously isolated from the species Rhodiola crenulata [38]. However, this is the first report of the isolation of these compounds in S. mauritianum.

Analysing the results of the tested activities (cytotoxicity, antiinflammatory, and anti-Alzheimer's) of the four compounds, we can observe that there is a significant difference in their pharmacological potential due to their lipophilic capacity. This is because the higher the partition coefficient ( $\log P$ ), the more lipophilic the compound is and, thus, it is better distributed in hydrophobic environments such as the lipid bilayers that make up cells [39]. Based on this premise, compounds 4 ( $\operatorname{cog} P=4.08)$ and 3 ( $\operatorname{cLog} P=3.67)$ exhibit higher lipophilicity compared to compounds 1 (cLog $P=1.91)$ and 2 (cLog $P=1.72)$.

Regarding the cytotoxic effects of the isolated compounds, there are no reports of their effects on cell viability. On the other hand, regarding the anti-inflammatory activity, there are only reports on compounds $\mathbf{2 , 3}$, and $\mathbf{4}$. In the case of compound $\mathbf{2}$, its anti-inflammatory effects were reported as inhibiting the induction of nitric oxide synthase, which subsequently inhibits the TNF- $\alpha$ and IL-1 $\beta$ inflammatory mediators in astrocyte, microglial, and macrophages cell lines at an $\mathrm{IC}_{50}$ of $5000 \mu \mathrm{M}$. However, in our study, the $\mathrm{IC}_{50}$ value obtained for this compound was 280 times less when tested in the C8D1A, Neuro-2a, and EOC 13.31 cell lines. For compound 3 , there are reports on its anti-inflammatory effects through the inhibition of CD40-TRAF6 (a protein involved in the NF- $K B$ pathway) in RAW 264.7 cells, with an $\mathrm{IC}_{50}$ of $16 \mu \mathrm{M}$ [40]. In our study, we report that compound 3 inhibited the production of NF- $\kappa$ B at an IC 50 five times less $(2.41-2.79 \mu \mathrm{M})$ when tested in the C8D1A, Neuro-2a, and EOC 13.31 cell lines. Lastly, although compound 4 has been reported to have no substantial activity as an inhibitor of NF- $K B$ at an IC $_{50}$ of $1.6 \mu \mathrm{M}$ in HEK293T (human embryonic kidney) and RAW 264.7 (mouse macrophage) cells [41], our study shows that compound $\mathbf{4}$ showed an inhibition of NF- $K B$ production in the C8D1A, Neuro-2a and EOC 13.31 cell lines, with $\mathrm{IC}_{50}$ values between 1.59-1.93 $\mu \mathrm{M}$. Therefore, if we consider that the mechanism of action of celastrol (positive control) is through the suppression of the degradation of $\mathrm{I} \beta \alpha \alpha$ and inhibition of the translocation of $\mathrm{p} 65$ 
of the nucleus [42], we can conclude that all compounds act on these factors on the NF- $\mathrm{BB}$ inhibition pathway.

Lastly, with regard to anti-Alzheimer's activity, there are no reports on the isolated compounds. In our case, the assay of antiA $\beta 42$ aggregation activity was performed by the thioflavin T (ThT) method. This assay depends on the measurement of the fluorescence emitted from incubating the mixture of $A \beta 42$ with ThT at various intervals of times. Over time, the intensity of the fluorescence increases in correspondence with the degree of amyloid aggregation in the presence of ThT. The degree at which the florescence is quenched in the presence of an anti-Alzheimer's agent is indicative of the inhibition of the $A \beta$ aggregation and, hence, the anti-Alzheimer's efficacy.

Although the percentage of $A C h E$ and $A B$ inhibition observed for the isolated compounds is equal to or less than the positive controls (galantamine and curcumin), the concentration at which they have produced such an effect is significantly lower. To determine whether they are more or less effective than the positive controls, the assays should have been performed using the same concentrations. However, this study was not carried out to determine only anti-Alzheimer's activity, but also to determine anti-inflammatory activity. In this sense, the concentrations that were tested for antiAlzheimer's activities were those that showed inhibition of NF- $\mathrm{KB}$.

In our study, the incubation of a mixture of $25 \mu \mathrm{M}$ of monomeric A $\beta 42$ and the compounds (at a concentration obtained from NF$\kappa \mathrm{B}$ inhibition) revealed that compound $\mathbf{4}$ has a higher pharmacological potential in comparison to curcumin and the other isolated compounds, due to its binding to amyloid fibrils $\beta 42$, inhibiting their aggregation [43]. Regarding the inhibition of AChE by the isolated compounds, compound $\mathbf{4}$ showed a higher activity due to its interaction with amino acid residues defining the active site of $\mathrm{AChE}$ via a hydrogen bond, hydrophobic, and $\pi-\pi$ interaction of its structure [44]. On the other hand, with respect to compound $\mathbf{1}$, there is only one report that shows its reactivating activity of AChE (16\%) at a concentration of $167 \mu \mathrm{M}$ [27]. However, in our case, compound 1 showed an inhibitory effect on AChE activity at a concentration 18 times less $\left(I_{50}=9.5 \mu \mathrm{M}\right)$.

This work has confirmed the anti-inflammatory (NF-kB inhibition) and anti-Alzheimer (AChE and $A \beta$ inhibitions) activities of $S$. mauritianum. Moreover, this study is the first report isolating 4-[(Z)(hydroxyimino)-methyl]- $\mathrm{N}, \mathrm{N}$-dimethylaniline (1), phenylacetic acid (2), (Z)-3-((2,5-dimethylphenyl)-amino)-1-phenylprop-2-en-1-one (3), and 1-(3,4,5-trihydroxyphenyl)-nonan-1-one (4) from S. mauritianum. For compounds $\mathbf{1}$ and $\mathbf{3}$, it is the first time that they have been isolated from a natural product, given that previous authors have only obtained these compounds through chemical synthesis. The current work has shown that all four compounds can be used for low-cost formulations and efficacious herbal drugs that could be beneficial globally against Alzheimer’s disease.

\section{Material and Methods}

\section{Plant material}

S. mauritianum was collected from the Cerro de Pasco community, Pasco province, Peru (10³9’53.0” S $\left.76^{\circ} 15^{\prime} 40.5^{\prime \prime} \mathrm{W}\right)$, in July 2019 , at an altitude of $4380 \mathrm{~m}$. The botanical identification was confirmed by the International Papa Centre (No. ARV 5643).

\section{Reagents}

First grade organic solvents were used for isolating the compounds and they were purchased from Sigma-Aldrich. Column chromatography was performed with silica gel (20-45 $\mu \mathrm{m}$ and $40-63 \mu \mathrm{m}$; Merck). TLC was performed using Merck Silica gel $60-\mathrm{F}_{254}$ plates. Chromatograms thus obtained were visualised by UV absorbance $(254 \mathrm{~nm})$ and through heating a plate stained with phosphomolybdic acid $\left(\mathrm{H}_{3} \mathrm{PMO}_{12} \mathrm{O}_{40}\right)$ solution in EtOH.

\section{NMR and MS analysis}

NMR experiments were performed on Bruker Advance DRX 300 and 500 spectrometers operating at $300,500\left({ }^{1} \mathrm{H}\right)$ or $76 \mathrm{MHz}$, and $126 \mathrm{MHz}\left({ }^{13} \mathrm{C}\right)$ with tetramethylsilane (TMS) as the internal standard. Spectra were calibrated by assignment of the residual solvent peak to $\delta_{\mathrm{H}} 7.26, \delta_{\mathrm{H}} 3.31$, and $\delta_{\mathrm{C}} 77.16$ for $\mathrm{CDCl}_{3}$ and $\delta_{\mathrm{C}} 49.00$ for MeOD. The complete assignment of protons and carbons was done by analysing the correlated ${ }^{1} \mathrm{H}-{ }^{1} \mathrm{H} C O S Y, H S Q C$, and $\mathrm{HMBC}$ spectra.

HR-ESI-MS (High-resolution electrospray ionisation mass spectrometry) analyses were performed using a mass spectrometer with a hybrid quadrupole time-of-flight analyser (model MAXIS II) from the commercial house Bruker, S.A. Samples were analysed using the electrospray ionisation technique by direct infusion at a flow of $3 \mu \mathrm{L} / \mathrm{min}$ using $\mathrm{MeOH}$ with $0.1 \%$ formic acid as the ionising phase. The source parameters were as follows: end plate offset: $500 \mathrm{~V}$; capillary: 3500 ; nebuliser: 0.2 bar; dry gas: $2.0 \mathrm{~L} / \mathrm{min}$; dry temp.: $250^{\circ} \mathrm{C}$; and mass range of 50-3000 Da.

\section{Extraction and isolation}

The dry powder of the leaves of $S$. mauritianum $(200 \mathrm{~g})$ was extracted by repeated maceration ( 3 times $/ 24 \mathrm{~h} / 25^{\circ} \mathrm{C}$ ) with $800 \mathrm{~mL}$ of different solvents, increasing the polarity: $\mathrm{HEX}, \mathrm{DCM}, \mathrm{MeOH}$, and $\mathrm{DH}_{2} \mathrm{O}$. Subsequently, the extracts were filtered, and the respective solvents were removed by vacuum rotary evaporation at room temperature $\left(25^{\circ} \mathrm{C}\right)$. As a result, four extracts of $2.8,3,2.5$, and $13 \mathrm{~g}$, respectively, were obtained.

The DCM extract $(3 \mathrm{~g})$ was selected as the most active one and was fractionated using a chromatographic column $(12 \times 60 \mathrm{~cm})$ with Si-60 Silica gel (40-63 $\mu \mathrm{m}$; Merck) as a stationary phase and a HEX/AcOEt gradient $(9: 1 \rightarrow 1: 1 \mathrm{v} / \mathrm{v})$ as the eluent. A total of eight fractions (F1-F8) were obtained, where fractions $\mathbf{F} \mathbf{2}(120 \mathrm{mg})$, F4 $(213 \mathrm{mg})$, and $\mathbf{F 5}(110 \mathrm{mg})$ showed higher biological activity.

Subsequently, based on the biological activity data, a second separation of $\mathbf{F} \mathbf{2}$ was carried out by using a chromatographic column $(2 \times 50 \mathrm{~cm})$ with Si-60 Silica gel $(20-45 \mu \mathrm{m}$; Merck) as a stationary phase and HEX/AcOEt (19:1). A total of four subfractions (2A-2 $\Delta$ ) were obtained, where fraction F2B showed higher biological activity. Finally, F2B was purified by a microcolumn using silica gel $(20-45 \mu \mathrm{m})$ as the stationary phase and HEX/AcOEt (3:1) as the mobile phase, obtaining compound $\mathbf{1}(6.8 \mathrm{mg})$.

Regarding $\mathbf{F 4}$, the separation was carried out using a chromatographic column $(2 \times 50 \mathrm{~cm})$ with Si-60 Silica gel $(20-45 \mu \mathrm{m}$; Merck) as a stationary phase and HEX/AcOEt (3:1). A total of five subfractions (4A-4E) were obtained, where F4B showed higher biological activity. Finally, F4B was purified by a microcolumn using 
silica gel (20-45 $\mu \mathrm{m})$ as the stationary phase and HEX/AcOEt (3:1) as the mobile phase, obtaining compound $\mathbf{2}(5.3 \mathrm{mg})$.

Subsequently, the separation of $\mathbf{F 5}$ was carried out by using a chromatographic column $(2 \times 50 \mathrm{~cm})$ with Si-60 Silica gel $(20-45$ $\mu \mathrm{m}$; Merck) as a stationary phase and HEX/AcOEt (3:1). A total of four subfractions (5A-5 $\mathbf{\Delta}$ ) were obtained. F5C (53 mg) showed higher biological activity. Finally, F5C was purified by a microcolumn using silica gel $(20-45 \mu \mathrm{m})$ as the stationary phase and HEX/ AcOEt (3:1) as the mobile phase, obtaining compounds $3(6.7 \mathrm{mg})$ and $4(4.1 \mathrm{mg})$.

A summary of the bioguided fractionation process can be observed in Fig. 49S, Supporting Information.

\section{Cell culture reagents and drugs}

Three Mus musculus cell lines were used in this study. C8D1A (mouse astrocyte, CRL-2541), Neuro-2a (mouse neuroblasts, CCL131), and EOC 13.31 (mouse microglia, CRL-2468) cells were used as a negative control to evaluate the cytotoxicity of the samples. All cell lines were obtained from the ATCC. Cells were cultured in specific media according to ATCC recommendations. The incubation condition for all cells was in an atmosphere of $95 \%$ air and $5 \%$ $\mathrm{CO}_{2}$ at $37^{\circ} \mathrm{C}$.

DMEM (Sigma-Aldrich), FBS (Summit Biotechnology), and PBS (SAFC Biosciences, Inc.) were used as culture mediums. L-glutamine was obtained from Applichem. Penicillin and streptomycin were purchased from Fisher Scientific. For cytotoxicity and activity assays, the compounds were dissolved in DMSO (Merck) at a concentration of $10 \mathrm{mM}$, while extracts and fractions were dissolved at $20 \mathrm{mg} / \mathrm{mL}$ in DMSO.

\section{Cytotoxicity assay}

Cells were seeded in 96 -well plates at a density of $5 \times 10^{4}$ cells/well and incubated overnight at $37^{\circ} \mathrm{C}$ in a humidified atmosphere of $5 \%$ $\mathrm{CO}_{2}$. Stock solutions of the samples were prepared by dissolving them in DMSO at a concentration of $20 \mu \mathrm{g} / \mathrm{mL}$ for the fractions and $10 \mu \mathrm{M}$ for the compounds. Subsequently, from the stock solutions, a series of dilutions were made until a final DMSO concentration of $0.1 \%$ was obtained in each of the wells of the plate for each of the tested concentrations [45]. The tested concentrations were 100 , $50,25,12.50,6.25,3.13,1.56,0.78,0.39$, and $0.20 \mu \mathrm{g} / \mathrm{mL}$ or $\mu \mathrm{M}$.

The XTT viability assay, inhibition of $\mathrm{H}_{2} \mathrm{O}_{2}$-induced cytotoxicity at various concentrations, was performed through the method of XTT formazan [46] using the abovementioned cell lines. These cells were sown in a 96 -well plate and allowed to grow at $37^{\circ} \mathrm{C}$. After $72 \mathrm{~h}$, the medium was removed from all wells. Fresh medium $(200 \mu \mathrm{L})$ was added to the control wells. Cells in each test well were treated with $0.1 \mathrm{mM} \mathrm{H}_{2} \mathrm{O}_{2}$ (prepared in medium) along with different concentrations of the samples. ACT ( $\geq 95 \%$; Sigma-Aldrich, CAS Number 50-76-0) was used as a positive control at a concentration of $0.01 \mu \mathrm{g} / \mathrm{mL}$ for the extract and fractions, equivalent to $0.008 \mu \mathrm{M}$. Cells in both control and test wells were reincubated for $72 \mathrm{~h}$, maintaining the same conditions. After the treatment incubation period, the medium in each well was substituted by $200 \mu \mathrm{L}$ of fresh medium, followed by the addition of $50 \mu \mathrm{L}$ of XTT $(0.6 \mathrm{mg} /$ $\mathrm{mL}$ ) containing $25 \mu \mathrm{M}$ peroxymonosulfate. The plate was further incubated for $4 \mathrm{~h}$ in the same conditions. Absorbance was meas- ured at $450 \mathrm{~nm}$ using a spectrophotometric ELISA plate reader (SpectraMax i3; Molecular Devices).

\section{NF-KB inhibition assay}

All cells were stably transfected with the KBF-Luc plasmid, which contains three copies of the NF- $k B$ binding site (from a major histocompatibility complex promoter) fused to a minimal simian virus 40 promoter driving the luciferase gene [47]. Cells ( $3 \times 10^{3}$ for cells) well) were seeded the day before the assay on a 96 -well plate. The cells were then treated with samples at the same concentrations used in the viability assays for $15 \mathrm{~min}$, and then they were stimulated with $30 \mathrm{ng} / \mathrm{mL}$ TNF- $\alpha$. Celastrol ( $\geq 98 \%$; Sigma-Aldrich, CAS Number 34157-83-0) was used as a positive control at a concentration of $3.34 \mu \mathrm{g} / \mathrm{mL}$ for the extract and fractions, equivalent to $7.41 \mu \mathrm{M}$. After $72 \mathrm{~h}$, the cells were washed twice with PBS and lysed in $50 \mu \mathrm{L}$ lysis buffer containing $25 \mathrm{mM}$ tris-phosphate $(\mathrm{pH}=7.8)$, $8 \mathrm{mM} \mathrm{MgCl}_{2}, 1 \mathrm{mM}$ dithiothreitol, $1 \%$ Triton X-100, and $7 \%$ glycerol, during $15 \mathrm{~min}$ at room temperature in a horizontal shaker. Luciferase activity was measured using a GloMax 96 microplate luminometer (Promega) following the instructions of the luciferase assay kit (Promega). The RLU was calculated, and the results are expressed as percentage of inhibition of NF- $\kappa$ B activity induced by TNF- $\alpha$ (100\% activation). The experiments for each concentration of the test elements were performed in triplicate wells.

\section{Acetylcholinesterase inhibitory activity}

AChE inhibition was determined by the method described by Khan et al. [48]. Samples were solubilised in $\mathrm{MeOH}$ and the tested concentrations were $100,50,25,12.5,6.3,3.1,1.6,0.8,0.4$, and $0.2 \mu \mathrm{g} / \mathrm{mL}$ (extracts and fractions) or $\mu \mathrm{M}$ (compounds). The reaction mixture contained $150 \mu \mathrm{L}$ of $(100 \mathrm{mM})$ sodium phosphate buffer $(\mathrm{pH}=8.0), 10 \mu \mathrm{L}$ of $5,5^{\prime}$-dithiobis-(2-nitrobenzoic acid) ( $\geq 98 \%$ DTNB; Sigma-Aldrich, CAS Number 69-78-3), $10 \mu \mathrm{L}$ of test sample solution, and $20 \mu \mathrm{L}$ of AChE solution (Sigma-Aldrich, CAS Number 9000-81-1). This mixture was homogenised and incubated for $15 \mathrm{~min}\left(37^{\circ} \mathrm{C}\right)$ followed by the addition of $10 \mathrm{~mL}$ of acetylthiocholine iodide ( $\geq 99 \%$; Sigma-Aldrich, CAS Number 1866-15-5) to initiate the reaction. Galantamine hydrobromide ( $\geq 94 \%$; Sigma-Aldrich, CAS Number 1953-04-4) was used as a positive control at a concentration of $4.31 \mu \mathrm{g} / \mathrm{mL}$ for the extract and fractions, equivalent to $11.70 \mu \mathrm{M}$. The assay was based on ATChI hydrolysis by AChE, obtaining 5-thio-2-nitrobenzoate anion, a mixture which turns yellow when forming complexes with DTNB. Finally, absorbance of the samples was recorded with a UV-Vis Shimadzu spectrophotometer at a wavelength of $412 \mathrm{~nm}$ (15 min).

\section{Assay of $\beta$-amyloid aggregation inhibitory activity}

The $A \beta$ aggregation was assessed using the ThT method described by Abouelela et al. [49]. Briefly, $25 \mu \mathrm{M} \mathrm{A} \beta 42$ (Peptide Institute, Inc.) were used; for the samples, the concentrations were the same as in the in vitro AChE assay, using a $50 \mathrm{mM}$ sodium phosphate buffer, $\mathrm{pH}=7.5,100 \mathrm{mM} \mathrm{NaCl}, 1 \%$ DMSO (v/v). The total fluid volume was $25 \mu \mathrm{L}$. Curcumin ( $\geq 94 \%$; Sigma-Aldrich, CAS Number 458-37-7) was used as a positive control at a concentration of $3.68 \mu \mathrm{g} / \mathrm{mL}$ for the extract and fractions, equivalent to $10 \mu \mathrm{M}$. Reactions were incubated at $37^{\circ} \mathrm{C}$ for $72 \mathrm{~h}$. Aliquots were diluted fourfold into $5 \mu \mathrm{M} \mathrm{ThT}$ 
and immediately evaluated for fluorescence (excitation $=445 \mathrm{~nm}$, emission $=490 \mathrm{~nm}$ ) to monitor the amount of $A \beta$ aggregate.

\section{Statistical analysis}

Cytotoxic concentration $50 \%\left(\mathrm{CC}_{50}\right)$ and inhibitory concentration $50 \%\left(\mathrm{IC}_{50}\right)$ values were determined by nonlinear regression. All experiments were performed in triplicate. One-way ANOVA statistical analysis (Tukey's multiple comparisons test, ${ }^{* *} \mathrm{p}<0.05 ;{ }^{* * *} \mathrm{p}<0.001$ ) was performed to evaluate the significant differences among values. All analyses were performed using GraphPad Prism, version 9.0.0.

\section{Supporting information}

${ }^{1} \mathrm{H}$ NMR, ${ }^{13} \mathrm{C}$ NMR, ${ }^{1} \mathrm{H}-{ }^{1} \mathrm{H}$ COSY, HSQC, HMBC, and MS spectra for extracts and isolated compounds are available as Supporting Information.

\section{Acknowledgments}

This work was supported by the National Herbarium of Bolivia, the Fundación de la Universidad Autónoma de Madrid (FUAM).

\section{Conflict of Interest}

The authors declare they have no conflict of interest.

\section{References}

[1] Alzheimer's Association Alzheimer's disease facts and figures. Alzheimer's Dement 2015; 11: 332-384

[2] Alzheimer's Association Alzheimer's disease facts and figures. Alzheimer's Dement 2020; 16: 391-460

[3] Breijyeh Z, Karaman R. Comprehensive Review on Alzheimer's Disease: Causes and Treatment. Molecules 2020; 25: 5789

[4] Vaz M, Silvestre S. Alzheimer's disease: Recent treatment strategies. Eur J Pharmacol 2020; 887: 173554

[5] Abeysinghe A, Deshapriya R, Udawatte C. Alzheimer's disease; a review of the pathophysiological basis and therapeutic interventions. Life Sci 2020; 256: 117996

[6] Guo T, Zhang D, Zeng Y, Huang TY, Xu H, Zhao Y. Molecular and cellular mechanisms underlying the pathogenesis of Alzheimer's disease. Mol Neurodegener 2020; 15: 1-37

[7] Megur A, Baltriukienė D, Bukelskienė V, Burokas A. The MicrobiotaGut-Brain Axis and Alzheimer's Disease: Neuroinflammation Is to Blame? Nutrients 2020; 13: 1-24

[8] Torres-Acosta N, O’Keefe JH, O’Keefe EL, Isaacson R, Small G. Therapeutic Potential of TNF- $\alpha$ Inhibition for Alzheimer's Disease Prevention. J Alzheimer Dis 2020; 78: 619-626

[9] Malafaia D, Albuquerque $H$, Silva A. Amyloid- $\beta$ and tau aggregation dual-inhibitors: A synthetic and structure-activity relationship focused review. Eur J Med Chem 2021; 214: 113209

[10] Ismaili L, do Carmo Carreiras M. Multicomponent Reactions for Multitargeted Compounds for Alzheimer's Disease. Curr Top Med Chem 2017; 17: 3319-3327

[11] Kokras N, Stamouli E, Sotiropoulos I, Katirtzoglou EA, Siarkos KT, Dalagiorgou G, Alexandraki KI, Coulocheri S, Piperi C, Politis AM. Acetyl Cholinesterase Inhibitors and Cell-Derived Peripheral Inflammatory Cytokines in Early Stages of Alzheimer's Disease. J Clin Psychopharmacol 2018; 38: 138-143
[12] Huang LK, Chao SP, Hu CJ. Clinical trials of new drugs for Alzheimer disease. J Biomed Sci 2020; 27: 1-13

[13] Andrade S, Ramalho M], Loureiro JA, Pereira M. Natural Compounds for Alzheimer's Disease Therapy: A Systematic Review of Preclinical and Clinical Studies. Int J Mol Sci 2019; 20: 2313

[14] Hoskin JL, Al-Hasan Y, Sabbagh MN. Nicotinic Acetylcholine Receptor Agonists for the Treatment of Alzheimer's Dementia: An Update. Nicotine Tob Res 2019; 21: 370-376

[15] Monacelli F, Acquarone E, Giannotti C, Borghi R, Nencioni A. Vitamin C, Aging and Alzheimer's Disease. Nutrients 2017; 9: 1-26

[16] Howes MR, Fang R, Houghton PJ. Effect of Chinese Herbal Medicine on Alzheimer's Disease. Int Rev Neurobiol 2017; 135: 29-56

[17] Kaunda JS, Zhang Y]. The Genus Solanum: An Ethnopharmacological, Phytochemical and Biological Properties Review. Nat Prod Bioprospect 2019; 9: 77-137

[18] Trevisan MTS, Macedo FVV. Seleção de plantas com atividade anticolinesterase para tratamento da doença de Alzheimer. Quim Nova 2003; 26: 301-304

[19] Ogunsuyi OB, Ademiluyi AO, Oboh G, Oyeleye SI, Dada AF. Green leafy vegetables from two Solanum spp. (Solanum nigrum $\mathrm{L}$ and Solanum macrocarpon $\mathrm{L}$ ) ameliorate scopolamine-induced cognitive and neurochemical impairments in rats. Food Sci Nutr 2018; 6: 860-870

[20] Safitri I, Hidayati HB, Turchan A. Suhartati, Khaerunnisa S. Solanum betaceum improves cognitive function by decreasing $\mathrm{N}$-methyl-Daspartate on alzheimer rats model. Int J App Pharm 2019; 11: 167-170

[21] Pelo SP, Adebo OA, Green E. Chemotaxonomic profiling of fungal endophytes of Solanum mauritianum (alien weed) using gas chromatography high resolution time-of-flight mass spectrometry (GC-HRTOF-MS). Metabolomics 2021; 17: 1-13

[22] Minghetti E, Olivera L, Montemayor SI. Ecological niche modelling of Gargaphia decoris (Heteroptera), a biological control agent of the invasive tree Solanum mauritianum (Solanales: Solanaceae). Pest Manag Sci 2020; 76: 1273-1281

[23] Jayakumar K, Meenu Krishnan VG, Murugan K. Evaluation of antioxidant and antihemolytic activities of purified caulophyllumine-A from Solanum mauritianum Scop. J Pharmacogn Phytochem 2016; 5: 195-199

[24] Jayakumar K, Murugan K. Pharmacological, Micromorphological Studies on Solanum mauritianum Scop. (Solanaceae): A Search. Int J Pharm Sci Rev Res 2015; 35: 134-139

[25] Jayakumar K, Murugan K. Purified solasodine and caulophyllumine: a from Solanum mauritianum Scop. against MCF-7 breast cancer cell lines in terms of cell growth, cell cycle and apoptosis. J Pharmacogn Phytochem 2017; 6: 472-478

[26] Gawinecki R, Kolehmainen E, Kauppinen R. ${ }^{1} \mathrm{H}$ and ${ }^{13} \mathrm{C}$ NMR studies of para-substituted benzaldoximes for evaluation of the electron donor properties of substituted amino groups. J Chem Soc Perkin Trans 2 1998; 1: 25-30

[27] Ribeiro TS, Prates A, Alves SR, Oliveira-Silva J], Riehl CAS, FigueroaVillar JD. The effect of neutral oximes on the reactivation of human acetylcholinesterase inhibited with paraoxon. J Braz Chem Soc 2012; 23: $1216-1225$

[28] Liu FF, Yang XY, Hao FH, Wang YI, Tang HR. Assignments of ${ }^{1} \mathrm{H}$ and ${ }^{13} \mathrm{C}$ NMR signals of 26 metabolites associated with the shikimate pathway. Magn Reson Chem 2017; 34: 311-322

[29] Chaitanya MVNL, Dhanabal SP, Pavithra N, Rama Satyanarayana Raju K, Jubie S. Phytochemical Analysis and In-vitro Antioxidant and cytotoxic activity of Aerial parts of Cestrum aurantiacum and Solanum mauritianum (Solanaceae weeds of Niligiris). Helix 2015; 3: 683-687

[30] Ravi V, Saleem TSM, Patel SS, Raamamurthy J, Gauthaman K. Anti-Inflammatory effect of methanolic extract of Solanum nigrum Linn berries. Int J Appl Res Nat Prod 2009; 2: 33-36 
[31] da Costa GA, Morais MG, Saldanha AA, Assis Silva IC, Aleixo ÁA, Ferreira JM, Soares AC, Duarte-Almeida JM, Lima LA. Antioxidant, Antibacterial, Cytotoxic, and Anti-Inflammatory Potential of the Leaves of Solanum lycocarpum A. St. Hil. (Solanaceae). Evid Based Complement Alternat Med 2015; 2015: 315987

[32] Rahman H, Rahman N, Haris M, Mahmood R. Antioxidant and anti-inflammatory potentials of Solanum pubescens Willd an ethnomedicinal plant of South Western Andhra Pradesh, India. J Res Pharm 2019; 23: 187-197

[33] Nwanna EE, Ibukun EO, Oboh G. Eggplant (Solanum spp) supplemented fruits diet modulated the activities of ectonucleoside triphosphate diphosphohydrolase (ENTPdase), monoamine oxidase (MAO), and cholinesterases (AChE/BChE) in the brain of diabetic Wistar male rats. J Food Biochem 2019; 43: e12910

[34] Javaid U, Javaid S, Ashraf W, Rasool MF, Normal OM, Alqahtani AS, Majeed A, Shakeel W, Albekairi TH, Alqahtani F, Imran I. Chemical Profiling and Dose-Dependent Assessment of Fear Reducing and Memory-Enhancing Effects of Solanum virginianum in Rats. Dose Response 2021; 19: 1559325821998486

[35] Seymour D, Wolfstirn KB. Substituted Styrenes. III. The Preparation of Some m- and p-Substituted $\alpha$-Methylstyrenes. J Am Chem Soc 1948; 70: 1177-1179

[36] Aoi Y, Tanaka K, Cook SD, Hayashi K, Kasahara H. GH3 auxin-amido synthetases alter the ratio of indole-3-acetic acid and phenylacetic acid in Arabidopsis. Plant Cell Physiol 2019; 61: 595-605

[37] Tengfei Y, Wei W, Ningning C, Jinchun C. Preparation method and application of $\mathrm{N}-\alpha \beta$ unsaturated ketone compound. PA. 2020; CN112552193. https://patentscope.wipo.int/search/es/detail. jsf?docld=CN321725271\&_cid=P20-KXG6XI-64400-1

[38] Wang Y, Tao H, Huang H, Xiao Y, Wu X, Li M, Shen J, Xiao Z, Zhao Y, Du F, Ji H, Chen Y, Cho CH, Wang Y, Wang S, Wu X. The dietary supplement Rhodiola crenulata extract alleviates dextran sulphate sodium-induced colitis in mice through anti-inflammation, mediating gut barrier integrity and reshaping the gut microbiome. Food Funct 2021; 12: 3142-3158

[39] Kapustikova I, Bak A, Gonec T, Kos J, Kozik V, Jampilek J. Investigation of Hydro-Lipophilic Properties of N-Alkoxyphenylhydroxynaphthalenecarboxamides. Molecules 2018; 23: 1-15

[40] Zarzycka B, Seijkens T, Nabuurs SB, Ritschel T, Grommes J, Soehnlein O, Schrijver R, Van Tiel CM, Hackeng TM, Weber C, Giehler F, Kieser A,
Lutgens E, Vriend G, Nicolaes GAF. Discovery of Small Molecule CD40-TRAF6 Inhibitors. J Chem Inf Model 2015; 55: 294-307

[41] Li L, Liu Y, Chen H, Li F, Wu J, Zhang H, He J, Xing Y, Chen Y, Wang X, Tian X, Li A, Zhang Q, Huang P, Lin T, Wu Q. Impeding the interaction between Nur77 and p38 reduces LPS-induced inflammation. Nat Chem Biol 2015; 11: 339-346

[42] Youn GS, Kwon DJ, Ju SM, Rhim H, Yong Soo Bae YS, Choi SY, Park J. Celastrol ameliorates HIV-1 Tat-induced inflammatory responses via NF-kappaB and AP-1 inhibition and heme oxygenase- 1 induction in astrocytes. Toxicol Appl Pharm 2014; 280: 42-52

[43] Sato M, Murakami K, Uno M, Nakagawa Y, Katayama S, Akagi K, Masuda Y, Takegoshi K, Irie K. Site-specific inhibitory mechanism for amyloid $\beta 42$ aggregation by catechol-type flavonoids targeting the Lys residues. J Biol Chem 2013; 288: 23212-23224

[44] Katalinić M, Rusak G, Domaćinović Barović ], Sinko G, Jelić D, Antolović $R$, Kovarik Z. Structural aspects of flavonoids as inhibitors of human butyrylcholinesterase. Eur J Med Chem 2010; 45: 186-192

[45] Park CH, Martinez BC. Enhanced release of rosmarinic acid from Coleus blumei permeabilized by dimethyl sulfoxide (DMSO) while preserving cell viability and growth. Biotechnol Bioeng 1992; 40: 459-464

[46] Tena Pérez V, Apaza Ticona L, Cabanillas HA, Maderuelo Corral S, Perles J, Rosero Valencia DF, Quintana AM, Ortega Domenech M, Rumbero Sánchez Á. Antitumoral potential of carbamidocyclophanes and carbamidocylindrofridin $A$ isolated from the cyanobacterium Cylindrospermum stagnale BEA 0605B. Phytochemistry 2020; 180: 112529

[47] Apaza Ticona L, Rumbero Sánchez Á, Sánchez Sánchez-Corral J, Iglesias Moreno P, Ortega Domenech M. Anti-inflammatory, pro-proliferative and antimicrobial potential of the compounds isolated from Daemonorops draco (Willd.) Blume. J Ethnopharmacol 2021; 268: 113668

[48] Khan RA, Khan MR, Sahreen S. Brain antioxidant markers, cognitive performance and acetylcholinesterase activity of rats: efficiency of Sonchus asper. Behav Brain Funct 2012; 8: 1-7

[49] Abouelela ME, Orabi M, Abdelhamid RA, Abdelkader M, Darwish F, Hotsumi M, Konno H. Anti-Alzheimer's flavanolignans from Ceiba pentandra aerial parts. Fitoterapia 2020; 143: 104541 